\title{
Suppression of regeneration in New Zealand mountain beech forests is dependent on species of introduced deer
}

\author{
Sean W. Husheer ${ }^{1,3, *}$, Robert B. Allen ${ }^{2} \&$ Alastair W. Robertson ${ }^{1}$ \\ ${ }^{1}$ Ecology Group, Institute of Natural Resources, Massey University, Private Bag 11222, Palmerston North, \\ New Zealand; ${ }^{2}$ Landcare Research, P.O. Box 69, Lincoln, New Zealand; ${ }^{3}$ Current Address: New Zealand \\ Forest Surveys, 15 McElwee Street, Jervoistown, Napier, New Zealand; *Author for correspondence \\ (e-mail: shusheer@clear.net.nz)
}

Received 17 May 2005; accepted in revised form 12 October 2005

Key words: browsing, Cervus elaphus, Cervus nippon, herbivory, Nothofagus solandri var. cliffortioides, red deer, sika deer

\begin{abstract}
We compared the impacts on forest regeneration of introduced sika (Cervus nippon) and red (Cervus elaphus) deer in New Zealand. Plot data were used to compare mountain beech (Nothofagus solandri var. cliffortioides) regeneration between a region with sika deer, and four regions without sika deer. All regions surveyed had red deer present. In the region where sika deer had been present for more than a decade, there was evidence of poor mountain beech seedling regeneration. In the four regions without sika deer, there was evidence of a strong regenerative response at stands with low occupancy by trees. When compared to larger deer species, sika deer have a digestive morphology allowing greater dietary versatility, which may result in them impeding forest regeneration where red deer do not. In contrast to mountain beech, some small-leaved shrub species may have been competitively advantaged by intensive browsing from sika deer. This is contra to a current view that small-leaved shrub species with interlacing branches were able to tolerate browsing from extinct ratite birds, but not introduced deer. Sika deer have been introduced into countries where other deer species are indigenous, such as Canada, Denmark, Great Britain, Czech Republic, Ireland and the United States of America. Because of their dietary advantage, sika deer may have a greater potential to impede forest regeneration and competitively exclude larger deer species, particularly at low basal area sites where impacts on tree regeneration are likely to be greatest.
\end{abstract}

\section{Introduction}

Linking disturbance and regeneration is a central theme in the study of forest dynamics (Pickett and White 1989) because many tree species rely on canopy tree death for regeneration. The regeneration process starts with density indepen-

* Nomenclature: Nomenclature for New Zealand plants follows Parsons et al. (1995). Coprosma tayloriae is described by Jane (2005) and Phyllocladus alpinus referred to by Wilson and Galloway (1993). dent canopy tree mortality that lowers stand occupancy by trees and increases the availability of light and nutrients for seedlings, which in turn leads to regeneration in many tropical and temperate hardwood forests (e.g. Canham 1988; Peterson et al. 1990; Denslow et al. 1998). Stand occupancy is frequently measured by tree basal area, which is a measure of the area that trees cover and is related to tree biomass. The effects of herbivores are often strongly related to stand occupancy (Russel et al. 2001; Horsley et al. 
2003). Despite this, few studies in temperate forests have considered the impacts of herbivores on canopy tree regeneration within a context of stand occupancy (but see Castleberry et al. 2000; Cornett et al. 2000; Husheer and Frampton 2005). This is a critical omission because herbivory may be concentrated at sites where canopy tree death has occurred (Peterson and Pickett 2000). At these sites resource availability is often higher, and nutrient- and light-demanding plants more common (Kelly 2002).

In New Zealand's widespread Nothofagus (southern beech) forests, previous studies on the impacts of red deer (Cervus elaphus L.), which were widely introduced into New Zealand in the 19th century (Challies 1985), have found that deer do not usually affect canopy replacement (e.g. James and Wallis 1969; Wardle 1984; Stewart and Harrison 1987; Stewart et al. 1987; Nugent 1988; but see also Conway 1949; Wardle 1962; Jane and Pracy 1974; Jane 1986). This may be because the influence of stand occupancy has not been specifically considered, even though beech species show prolific regeneration with lowered stand occupancy (Wardle and Guest 1977; Allen and Allan 1997). Alternatively, beech species may be resistant to mammalian herbivory after having evolved a small-leaved growth form, under the browsing influences of a suite of now extinct avian herbivore species including the deer-sized moa (Diornis spp.; Atkinson and Greenwood 1989; Diamond 1990). Hunting and habitat destruction from Polynesians, soon after their colonisation of New Zealand in the last 600 years, probably caused the extinction of most indigenous terrestrial avian herbivores (Holdaway and Jacomb 2000). This meant that there was minimal browsing from terrestrial vertebrates in beech forests from the time of these extinctions until the introduction of ungulates such as red deer. Sika deer (Cervus nippon Temm.) were liberated in the central North

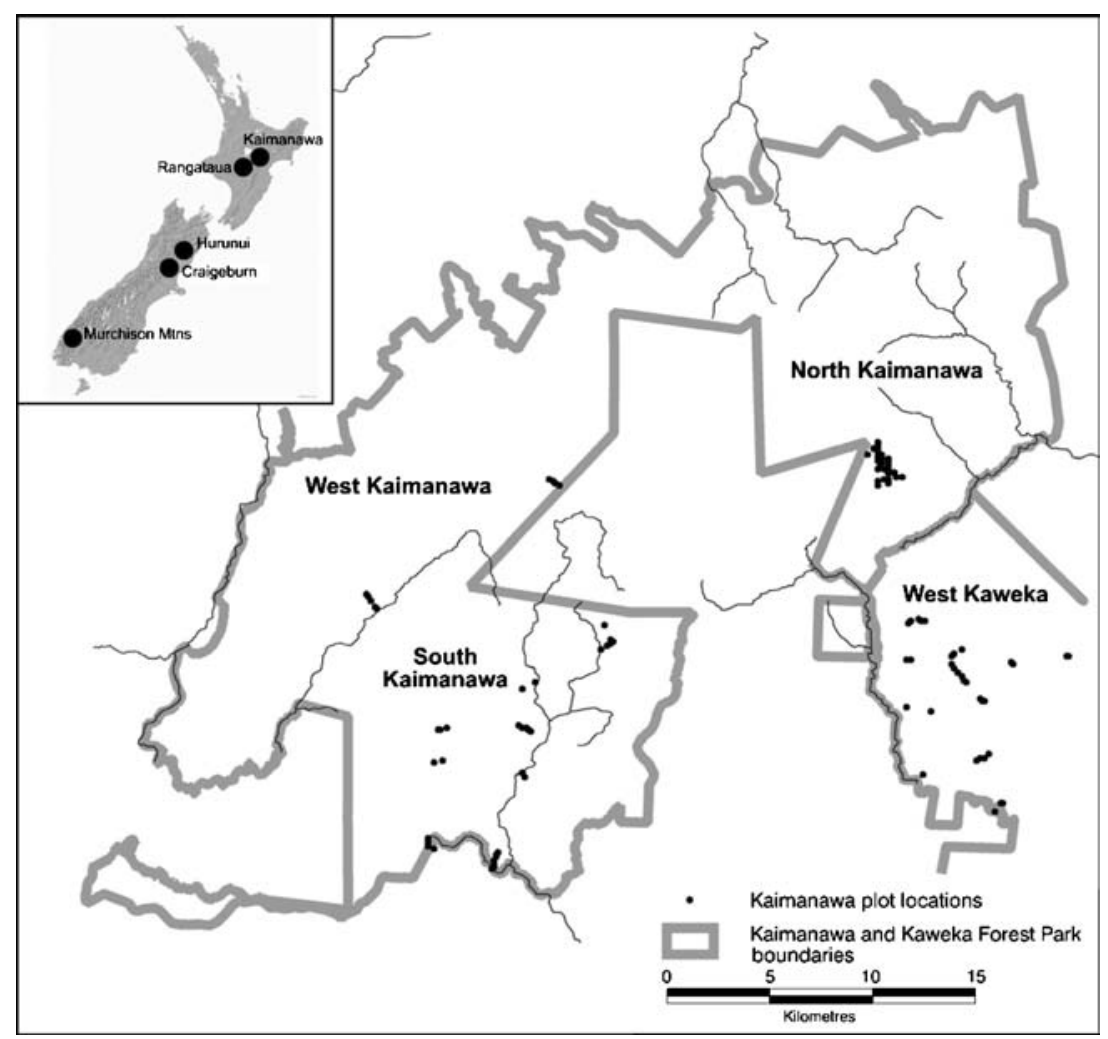

Figure 1. Map of randomly selected Kaimanawa transect locations. Inset are New Zealand's North and South Islands showing study areas in Kaimanawa ecological region, Rangataua Forest, Hurunui, Craigieburn, and Murchison Mountains. 
Island in 1905 (Davidson 1979; Figure 1), but colonised more slowly than red deer (Elder 1956). Because of this slower rate of dispersal, there is a distinct history of colonisation of central North Island mountain beech (Nothofagus solandri var. cliffortioides) forests first by red deer, then by sika deer, followed by reduced abundance of red deer (Davidson and Fraser 1991).

Earlier New Zealand studies have often not differentiated between impacts of different species of introduced ungulate (e.g. Wardle et al. 2001; Bellingham and Allan 2003), although different species of ungulates may have different effects through either competition (Murray and Illius 2000) or facilitation (Arsenault and Owen-Smith 2002). Larger forest dwelling ungulates with relatively slow digestion, and large mouths, bodies and rumens, such as red deer, are better adapted to grazing plants high in cellulose such as grasses (Hanley 1997). In comparison, ungulates such as sika deer with different digestive morphology (Fraser 1996) and higher dietary versatility (Asada and Ochiai 1996) are better adapted to browsing small-leaved shrubs and plants high in chemicals such as monoterpenes and phenols that interfere with rumen microbial activity (Duncan et al. 1994). This is likely to allow a greater dietary concentration of plants with well-developed chemical and morphological defence strategies. This suggests that sika deer are likely to have higher impacts on tree and shrub species that are only moderately palatable to red deer such as mountain beech (Husheer et al. 2003). Observations of rumen contents from the central North Island show that beech species are nearly twice as common in the diet of sika deer as they are in red deer (Nugent et al. 2000). Previous studies in Japan have shown that where sika deer are present in large numbers for several decades, impacts on beech (Fagus crenata) forest regeneration can be strong (Takatsuki and Gorai 1994; Tsujino and Yumoto 2004). If impacts of sika deer over time are cumulative, New Zealand species that are palatable to sika deer such as broadleaf (Griselinia littoralis) and mountain beech might be more common in recently colonised areas. In areas with longer histories of colonisation by sika deer, divaricating shrubs with fewer leaves on their outer canopy and strong, acutely-angled branchlets, may become more common if their growth form is tolerant of browsing from terrestrial vertebrates (Atkinson and Greenwood 1989). There is also likely to be fine-scale variation in deer impacts independent of the colonisation history of deer due to factors such as plant species composition and habitat productivity. In New Zealand southern beech forests, the lowering of basal area following natural disturbance increases the availability of light and nutrients to seedlings and saplings (Allen et al. 1997) thereby increasing the nutrient content of those plants (Davis et al. 2003). If palatable plants such as mountain beech increase in abundance and growth in the browse tier at low basal area sites due to increased resource availability (Wardle 1984), this may attract deer to such sites. If deer are able to suppress regeneration of mountain beech then this is likely to be most pronounced at low basal area sites.

To contrast the impacts of sika and red deer on mountain beech regeneration, we first compare the abundance of mountain beech seedlings within a region containing both red and sika deer with four other regions where red but not sika deer are present. Second, we test whether the progressive sika deer colonisation of four areas in the region with sika deer has affected mountain beech seedling abundance and the frequency of occurrence of small-leaved trees and shrubs. If sika deer are able to suppress the regeneration of mountain beech, then browseresistant trees should occur more frequently in areas where these plants were first released from competition from mountain beech, and least in areas where sika deer are not present. Finally, we consider the results from this study in a context of recent studies on the evolution of herbivory resistance in the New Zealand flora, and the implications for other regions around the world where sika deer have been introduced.

\section{Methods}

Sika deer study areas

In the Kaimanawa region of New Zealand $\left(39^{\circ}\right.$ $\left.\mathrm{S}, 176^{\circ} \mathrm{E}\right)$ one hundred and eight $20 \mathrm{~m} \times 20 \mathrm{~m}$ survey plots were measured on 30 randomly 
located transect lines in mountain beech forest between January 1999 and April 2001. The plots were located in four contiguous areas that all had established populations of red deer by 1930 (Elder 1962), but with different histories of colonisation by sika deer. Northern Kaimanawa (29 plots, 8 transects, $1180-1380 \mathrm{~m}$ altitude) was the closest area to the sika liberation point, and sika deer became conspicuous there in the 1930s (Davidson 1973) following likely colonisation from their liberation point during the late 1920s. The Sika deer probably colonised the western Kaweka area (34 plots, 12 transects, 840$1360 \mathrm{~m}$ ) in the 1940s and had displaced red deer at some sites there in the 1950s (Davidson and Fraser 1991). The western Kaimanawa area (10 plots, 2 transects, $700-1340 \mathrm{~m}$ ) was probably colonised by sika deer through open grasslands and plantation forestry to the north of Kaimanawa Forest Park in the 1960s before being more commonly observed there in the early 1970s (Davidson 1973). In the southern Kaimanawa area (35 plots, 8 transects, $860-1380 \mathrm{~m}$ ) sika deer only became dominant over red deer during the mid1990s (pers. obs. SWH) and so probably colonised this area during the 1980s.

The Kaimanawa region consists of a series of ranges characterised by high relief, with often steep valley walls, valley bottoms often less than $500 \mathrm{~m}$ and a high point of $1727 \mathrm{~m}$ in the southern Kaimanawa. Soils are either derived from the predominantly sandstone bedrock or from ash from volcanic eruptions (ca. 1800 years BP, Wilson 1993). At the Boyd Airstrip, central Kaimanawa Forest Park, rainfall averages $2083 \mathrm{~mm} \mathrm{yr}^{-1}$, but it decreases further east in Kaweka Forest Park (1580 $\mathrm{mm} \mathrm{yr}^{-1}$ ).

\section{Red deer regions and sampling approach}

We found four surveys in the National Vegetation Surveys databank (Wiser et al. 2001) that were undertaken since 1998 in mountain beech forests throughout New Zealand, and where red but not sika deer were present. As in the Kaimanawa region, the surveys in these four regions were undertaken in unlogged southern beech dominated forest. The Craigieburn region is almost completely dominated by mountain beech occurring on sandstone bedrock derived soils (34 plots, 13 transects, $43^{\circ} \mathrm{S} 171^{\circ} \mathrm{E}, 1400 \mathrm{~mm} \mathrm{yr}^{-1}$ rainfall, 800-1300 $\mathrm{m}$ altitude). In comparison, in the four other regions (Kaimanawa inclusive) mountain beech forms the treeline below $1400 \mathrm{~m}$ altitude but is replaced by red ( $N$. fusca) and silver beech ( $N$. menziesii) at lower altitudes. Rangataua Forest (13 plots, 5 transects, $39^{\circ} \mathrm{S}$ $175^{\circ} \mathrm{E}$ ) occurs on a basalt lava flow on southern Mt. Ruapehu. Hurunui Valley has sandstone bedrock with steep, glacier formed valley sides ( 5 plots, 3 transects, $43^{\circ} \mathrm{S} 172^{\circ} \mathrm{E}$ ), and the Murchison Mountains consist of glacier formed valleys with granite derived soils (16 plots, 6 transects, $45^{\circ} \mathrm{S} 167^{\circ} \mathrm{E}, 2400-4500 \mathrm{~mm}$ rainfall).

\section{Plot measurement procedure}

In all surveys, transects originated at randomly selected points on watercourses and terminated at the nearest highpoint or treeline, except for northern Kaimanawa where transect origins were at randomly located points and followed randomly selected compass bearings. On each transect, plots were established $40 \mathrm{~m}$ from transect origins and at $200 \mathrm{~m}$ intervals from the origin thereafter. Only large ( $>100 \mathrm{ha}$ ) areas of mountain beech dominated forest (determined by proportion of basal area) were sampled.

All eight surveys in this study used a protocol for $20 \mathrm{~m} \times 20 \mathrm{~m}$ plot measurement described by Allen (1993). For the overstorey, species of all trees $>30 \mathrm{~mm}$ diameter over bark at breast height $(\mathrm{DBH}$ measured at $135 \mathrm{~cm})$ rooted within plots were identified, and their stem diameter measured. Mountain beech has periodic and variable seeding, often resulting in large numbers of small ( $<15 \mathrm{~cm}$ high) ephemeral seedlings (Wardle 1984). Therefore, we counted established seedlings (15-135 cm height tier) within 24 systematically located $0.49 \mathrm{~m}$ radius sub-plots within each plot. To determine woody species composition in the understorey, the presence of tree and shrub (distinguished using the criteria of Poole and Adams 1994) seedlings (15-135 cm tall) were recorded by species in these sub-plots.

\section{Data analysis}

Data for mountain beech seedling abundance in sub-plots was pooled for each plot and $\log _{e^{-}}$ 
transformed to meet assumptions of ANOVA. Contrasts of seedling abundance between areas with and regions without sika deer were made using SYSTAT (SPSS 2000). Detrended correspondence analysis (DCA) in CANOCO 4.0 was used to produce plot ordination scores of understorey and overstorey composition (Ter Braak and Smilauer 1998) using frequency of occurrence of seedlings $(15-135 \mathrm{~cm})$ in 24 sub-plots and relative live tree basal area to calculate respective importance values. Understorey species composition is likely to be influenced by overstorey composition and site basal area, so we tested whether overstorey composition was comparable between regions and used basal area as a covariate in comparisons of seedling composition. First and second axis DCA scores, mean tree density, basal area, and understorey frequency of occurrence were compared using ANOVAs, with the Bonferroni correction for multiple comparisons (Sokal and Rohlf 1995). Because individual transects started in valley bottoms and ended at highpoints, or at treeline, there was a large variation in plot altitude within transects. Hypothesis tests among areas and regions used an error term of transects nested within areas or regions, to allow for this variation and avoid pseudoreplication at the plot level.

\section{Results}

Contrasts between regions with and without sika deer

Mountain beech seedling abundance was significantly higher in regions with no sika deer present $\left(\log _{\mathrm{e}}+1 ; 22,025\right.$ seedlings ha ${ }^{-1}, 24$ transects, 76 plots) compared to four areas in the Kaimanawa region where the deer were present (664 seedlings $\mathrm{ha}^{-1} ; 29$ transects, 108 plots; $F_{1,51}=18.096$, $P<0.001)$. Basal area was used as a covariate, and had a significant effect $\left(F_{1,127}=11.760\right.$, $P=0.001)$ confirming that seedling abundance was affected by differences in basal area. In regions without sika deer there was a clear negative relationship between seedling abundance and plot basal area $\left(F_{1,74}=31.124, \quad R^{2}=0.296\right.$, $P<0.001)$, particularly for data from Rangataua and Craigieburn (Figure 2). In contrast, the four

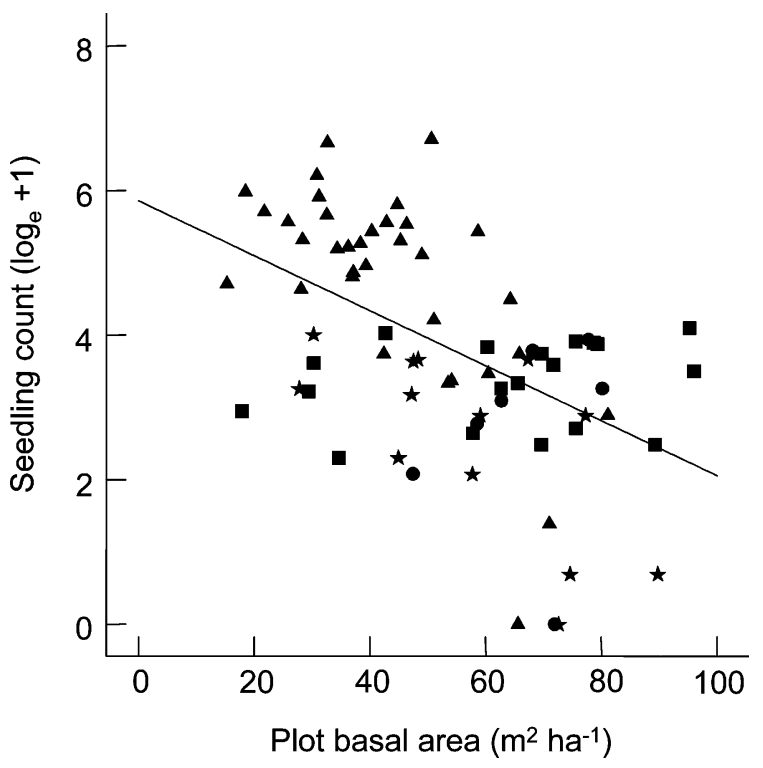

Figure 2. Relationship between the number of mountain beech seedlings $\left(\log _{\mathrm{e}}+1\right)$ counted in twenty-four $0.75 \mathrm{~m}^{2}$ subplots in each $20 \mathrm{~m} \times 20 \mathrm{~m}$ plot and plot basal area $\left(\mathrm{m}^{2} \mathrm{ha}^{-1}\right)$ for 66 plots in four areas outside the Kaimanawa region where sika deer are not present. These areas are Craigieburn

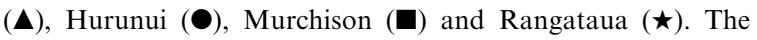
regression equation is seedling count $\left(\log _{\mathrm{e}}+1\right)=5.814-0.037$ $\times$ basal area.

Kaimanawa region areas showed no such relationship $\left(F_{1,106}=0.276, \quad R^{2}=0.003, \quad P=0.600\right)$ demonstrating that seedling abundance at low basal area sites where sika deer are present are particularly low in comparison to similar sites with no sika deer (Figure 3). There was no significant difference in seedling abundance among the four regions with no sika deer $\left(F_{3,23}=2.916\right.$, $P=0.056$ ) when basal area was included as a covariate, demonstrating that these regions had consistently higher seedling densities than the Kaimanawa region.

The basal area of G. littoralis and celery pine (Phyllocladus alpinus) was higher in the Kaimanawa region, while mountain and silver beech and total basal area were higher in the four regions with no sika deer (Table 1). In contrast, first axis DCA scores calculated using relative basal area were not significantly different between the Kaimanawa region (mean score \pm $\mathrm{SE}=0.75 \pm 0.03)$ and regions without sika deer (mean $\pm \mathrm{SE}=0.59 \pm 0.02 ; \quad F_{1,52}=3.002, \quad P=$ 0.089 ) showing that differences in basal area of 


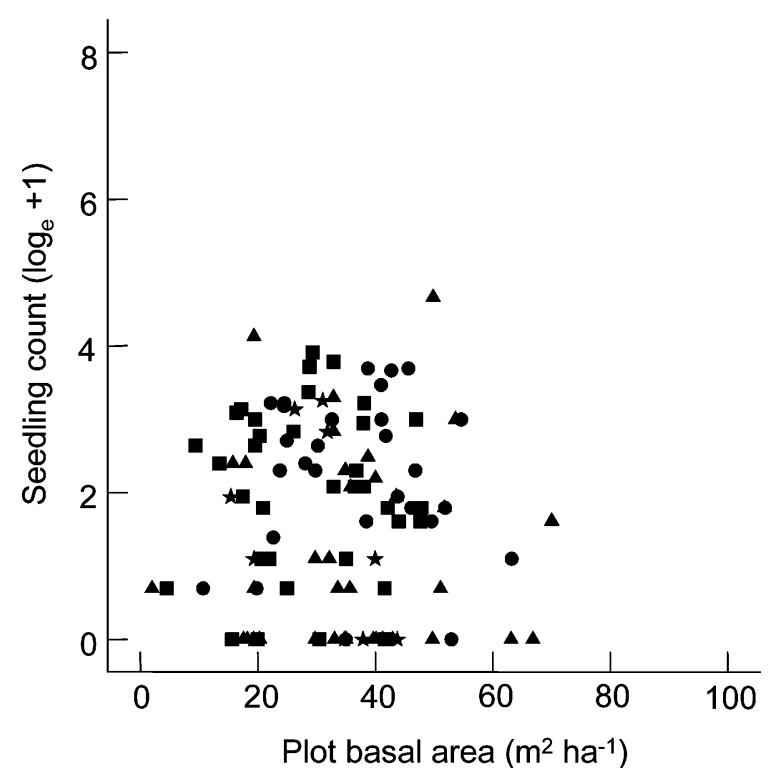

Figure 3. The relationship between the number of mountain beech seedlings $\left(\log _{\mathrm{e}}+1\right)$ counted in twenty-four $0.75 \mathrm{~m}^{2}$ subplots in each $20 \mathrm{~m} \times 20 \mathrm{~m}$ plot and plot basal area $\left(\mathrm{m}^{2} \mathrm{ha}^{-1}\right)$ in the Kaimanawa region where sika deer are present. Data are from 108 plots in western Kaweka $(\boldsymbol{\Delta})$, and northern $(\boldsymbol{O})$, western (ם) and southern Kaimanawa Forest Parks $(\star)$.

individual species did not have a large effect on differences in overall species composition. Tree abundance data were consistent with this result: apart from silver beech being more common in areas without sika deer, there was no overall difference in tree stem density for species with $>100$ stems ha $^{-1}$ between Kaimanawa and regions without sika deer.

Total tree and shrub seedling $(15-135 \mathrm{~cm}$ tall) frequency of occurrence did not differ between Kaimanawa and regions without sika deer, but some individual species did differ in occurrence between the regions. Mountain beech had over twice the frequency of occurrence in regions without sika deer, which is consistent with seedling abundance comparisons of this species. Conversely, the occurrence of seedlings of the browse-resistant small-leaved shrubs Coprosma tayloriae and Myrsine divaricata was ca. five times higher in the Kaimanawa region compared to regions without sika deer. These differences led to significant differences in woody seedling composition, calculated using frequency of occurrence at plots with woody species present, between areas with sika deer (mean axis 1 DCA score $\pm \mathrm{SE}=2.51 \pm 0.6)$ and regions without sika deer (mean axis 1 DCA score $\pm \mathrm{SE}=$ $\left.0.99 \pm 0.8 ; F_{1,49}=53.745, P<0.001\right)$. When basal area was used as a covariate it did not have a significant effect on DCA scores for woody seedling frequencies of occurrence $\left(F_{1,115}=0.521\right.$, $P=0.472$ ).

\section{Contrasts among areas with different histories of sika deer colonisation}

There was no significant difference in basal area among Kaimanawa areas for the stand dominants (G. littoralis, mountain and silver beech, and P. alpinus; Table 2). Differences in the abundance of the small-leaved trees Coprosma pseudocuneata and P. alpinus did not appear to be related to the history of colonisation by sika deer. There was no significant difference in mountain beech seedling density (stems ha ${ }^{-1}$, $\left.\log _{\mathrm{e}}+1\right)$ among the four Kaimanawa areas when plot basal area $\left(\mathrm{m}^{2} \mathrm{ha}^{-1}\right)$ was used as a covariate $\left(F_{3,26}=1.423, P=0.259\right)$ and therefore, no indication that the different colonisation history of the four areas influenced mountain beech seedling density.

\section{Discussion}

Mountain beech seedling abundance was high at low basal area sites, but only in the absence of sika deer. This confirms the importance of low basal area sites for mountain beech regeneration (Wardle 1970; Ogden et al. 1996), and is likely to be due to increasing nutrient and light availability following disturbance (Allen et al. 1997; Clinton et al. 2002). Where sika deer had colonised mountain beech seedling abundance was low at all plots, and did not increase with low basal area. Differences in the level of regeneration between areas with and without sika deer were so profound on a landscape scale that the impacts of sika deer appear to be the most plausible explanation for the suppressed mountain beech regeneration observed throughout the Kaimanawa region. Independent introductions of species into new ranges in a replicated manner are rare, so comparative studies such as ours are often the only possible approach to study introduced 
Table 1. Means $( \pm \mathrm{SE})$ of plot basal area, relative basal area (for species with basal area $>1.0 \mathrm{~m}^{2} \mathrm{ha}^{-1}$ ), tree stem density (for species with tree abundance $>100$ stems $\mathrm{ha}^{-1}$ ) and frequency of occurrence of woody seedlings (for species with $>10 \%$ occurrence in sub-plots) with Bonferroni adjusted $F$-tests.

\begin{tabular}{|c|c|c|c|c|}
\hline & Without sika deer & With sika deer & $F$ & $P$ \\
\hline \multicolumn{5}{|l|}{ Basal area $\left(m^{2} h a^{-1}\right)$} \\
\hline Griselinia littoralis & $0.1 \pm 0.1$ & $2.3 \pm 0.3$ & 16.913 & $<0.001$ \\
\hline Silver beech & $6.9 \pm 1.7$ & $0.4 \pm 0.1$ & 25.49 & $<0.001$ \\
\hline Mountain beech & $46.1 \pm 2.2$ & $26.6 \pm 1.3$ & 47.717 & $<0.001$ \\
\hline Phyllocladus alpinus & $0.2 \pm 0.1$ & $1.0 \pm 0.1$ & 8.455 & 0.020 \\
\hline All species & $55.8 \pm 2.5$ & $33.1 \pm 1.3$ & 87.819 & $<0.001$ \\
\hline \multicolumn{5}{|c|}{ Relative basal area (\% of mean plot relative basal) } \\
\hline G. littoralis & $0.2 \pm 0.1$ & $8.0 \pm 1.2$ & 15.312 & 0.001 \\
\hline Silver beech & $9.5 \pm 2.0$ & $3.0 \pm 1.2$ & 20.805 & $<0.001$ \\
\hline Mountain beech & $86.0 \pm 2.3$ & $78.4 \pm 2.2$ & 0.850 & 1.000 \\
\hline Phyllocladus alpinus & $0.4 \pm 0.2$ & $3.4 \pm 0.5$ & 11.469 & 0.005 \\
\hline \multicolumn{5}{|c|}{ Tree density (stems $h a^{-1}$ ) } \\
\hline C. tayloriae & $58 \pm 23$ & $281 \pm 46$ & 0.725 & 1.000 \\
\hline Silver beech & $257 \pm 57$ & $31 \pm 12$ & 16.36 & $<0.001$ \\
\hline Mountain beech & $1704 \pm 152$ & $1219 \pm 113$ & 0.27 & 1.000 \\
\hline P. alpinus & $58 \pm 23$ & $244 \pm 30$ & 4.109 & 0.110 \\
\hline All species & $2267 \pm 168$ & $2248 \pm 139$ & 4.281 & 0.095 \\
\hline \multicolumn{5}{|c|}{ Seedling frequency of occurrence in sub-plots (\%) } \\
\hline C. foetidissima & $4 \pm 1$ & $12 \pm 2$ & 0.705 & 1.000 \\
\hline C. pseudocuneata & $9 \pm 2$ & $16 \pm 2$ & 1.324 & 1.000 \\
\hline C. tayloriae & $9 \pm 3$ & $33 \pm 2$ & 23.488 & $<0.001$ \\
\hline M. divaricata & $3 \pm 1$ & $16 \pm 2$ & 8.976 & 0.016 \\
\hline Mountain beech & $57 \pm 4$ & $18 \pm 2$ & 47.599 & $<0.001$ \\
\hline Mean of plot totals & $113 \pm 9$ & $154 \pm 9$ & 0.335 & 1.000 \\
\hline
\end{tabular}

All tests contrast four regions without sika deer with four areas within the Kaimanawa region where sika deer are present. Contrasts of seedling frequency of occurrence use plot basal area as a covariate.

organisms, but the causes of observed effects are never completely irrefutable unless alternate explanations can be ruled out (Oksanen 2001). There are three lines of reasoning that support a conclusion that sika deer are capable of suppressing mountain beech regeneration.

First, the morphology of sika deer provides this species with the potential to browse more intensively than red deer on seedlings of trees and shrubs (Fraser 1996; Hanley 1997) enabling them to maintain high reproductive rates, associated with better physiological condition, in depleted forest habitats (Asada and Ochiai 1996). This may allow sika deer to suppress mountain beech seedling regeneration where red deer would not, and to maintain higher population densities than red deer. Results from pellet frequency of occurrence surveys suggest that both red and sika deer populations can maintain high levels of abundance, but that red deer populations decline with commercial hunting pressure, or immediately following the colonisation of sika deer
(Davidson 1973; Davidson and Fraser 1991). In the three Kaimanawa areas deer faecal pellet frequency of occurrence in $114 \mathrm{~cm}$ radius plots (an index of deer abundance, Riney 1957) was $>30 \%$ between 1980 and 1988, and in 2004 was $33 \%$ despite ongoing hunting during that time. In Kaweka Forest Park, pellet frequency of occurrence was $11 \%$ in 1981 and $10 \%$ in 2000 (Husheer 2003). In contrast, in the Craigieburn and Murchison Mountain regions these indices of deer abundance were formerly high but declined following the initiation of commercial deer recovery operations in the 1970s (Craigieburn $1978=33 \% ; \quad 1983=17 \% \quad$ Coomes et al. 2003; Murchison $1969=14 \%, 1977=4 \%$ Parkes et al. 1978). In the Rangataua region, where commercial hunting has not been allowed, pellet occurrence was more moderate in 2003 (16\% Husheer, unpub. data). Using data from deer culling and pellet frequency of occurrence, Husheer and Robertson (2005) estimated that there were $>16$ deer $\mathrm{km}^{-2}$ in an area adjacent to 
Table 2. Mean ( $\pm S E$ ) basal area (for species with basal area $>1 \mathrm{~m}^{2} \mathrm{ha}^{-1}$ ) and tree stem density (for stems $>30 \mathrm{~mm} \mathrm{DBH}$ and

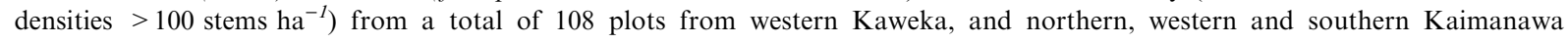
Forest Parks.

\begin{tabular}{|c|c|c|c|c|c|c|}
\hline Species & $\begin{array}{l}\text { North Kaimanawa } \\
(n=30)\end{array}$ & $\begin{array}{l}\text { West Kaweka } \\
(n=35)\end{array}$ & $\begin{array}{l}\text { West Kaimanawa } \\
(n=10)\end{array}$ & $\begin{array}{l}\text { South Kaimanawa } \\
(n=35)\end{array}$ & $F$ & $P$ \\
\hline Sika dominance & $\approx 1930 \mathrm{~s}$ & $\approx 1950 \mathrm{~s}$ & $\approx 1970 \mathrm{~s}$ & $\approx 1990 \mathrm{~s}$ & & \\
\hline \multicolumn{7}{|c|}{ Basal area $\left(m^{2} h a^{-1} \pm S E\right)$} \\
\hline Mountain beech & $29.1 \pm 3.0$ & $30.8 \pm 2.8$ & $23.1 \pm 4.3$ & $24.72 \pm 2.5$ & 1.232 & 1.000 \\
\hline G. littoralis & $1.5 \pm 0.7$ & $3.4 \pm 0.7$ & $1.7 \pm 1.0$ & $2.01 \pm 0.6$ & 0.751 & 1.000 \\
\hline Silver beech & $1.3 \pm 0.5$ & $<0.1 \pm<0.1$ & 0 & 0 & 3.618 & 0.130 \\
\hline P. alpinus & $0.9 \pm 0.3$ & 1. $1 \pm 0.3$ & $2.3 \pm 0.4$ & $0.8 \pm 0.3$ & 2.308 & 0.495 \\
\hline All 26 species & $32.6 \pm 2.8$ & $36.0 \pm 2.7$ & $27.6 \pm 4.0$ & $27.7 \pm 2.4$ & 1.621 & 1.000 \\
\hline \multicolumn{7}{|c|}{ Tree stem density (stems $h a^{-1} \pm S E$ ) } \\
\hline Mountain beech & $1197.1 \pm 257.0$ & $644.4 \pm 243.3$ & $1785.0 \pm 367.0$ & $1529.4 \pm 218.0$ & 5.158 & 0.042 \\
\hline C. pseudocuneata & $378.0 \pm 49.8$ & $21.7 \pm 47.1$ & $177.5 \pm 70.9$ & $140.9 \pm 42.2$ & 8.266 & 0.003 \\
\hline$P$. alpinus & $209.6 \pm 69.2$ & $258.3 \pm 65.4$ & $532.5 \pm 98.6$ & $206.6 \pm 58.7$ & 2.971 & 0.343 \\
\hline C. tayloriae & $123.1 \pm 97.4$ & $291.2 \pm 92.1$ & $575.0 \pm 139.0$ & $187.2 \pm 82.6$ & 1.567 & 1.000 \\
\hline G. littoralis & $67.0 \pm 34.3$ & $125.4 \pm 32.4$ & $52.5 \pm 48.8$ & $103.5 \pm 29.1$ & 0.391 & 1.000 \\
\hline M. divaricata & $<0.1 \pm 22.7$ & $68.2 \pm 21.5$ & $185.0 \pm 32.3$ & $10.4 \pm 19.2$ & 22.962 & $<0.001$ \\
\hline All 26 species & $2105.9 \pm 319.0$ & $1586.8 \pm 301.2$ & $3412.5 \pm 454.0$ & $2418.0 \pm 270.0$ & 4.928 & 0.049 \\
\hline
\end{tabular}

Bonferroni corrections for multiple comparisons have been applied and decades when sika deer probably became dominant over red deer are listed.

the western Kaweka area in 1998, whereas Nugent and Fraser (1993) estimated that deer had an average population density throughout New Zealand forests of ca. 4 deer $\mathrm{km}^{-2}$ in 1988 following two decades of intense commercial hunting. Even though sika deer are ca. half the size of red deer, this difference in biomass still represents considerably more potential browsing pressure. The ability of sika deer to occupy small home ranges may also contribute to their potential to more intensively browse forests (Endo and Doi 1996). There is also evidence from studies of sika deer in Japan relating body size to dietary preferences. Sika deer from northern study sites in Japan tend to be larger and to graze graminoids more than the smaller sika deer from southern study areas, which tend to browse on herbs (Asada and Ochiai 1996; Jayasekara and Takatsuki 2000). Deer in the south of Japan also occur in habitats with a relatively stable food supply, whereas in the north there is considerable seasonal variation in the quality of food. This places dietary stress on animals during winter (Takatsuki and Ikeda 1993; Asada and Ochiai 1999) when unpalatable plants are increasingly browsed (Takahashi and Kaji 2001).

Second, exclosure plot studies in the Kaimanawa sika deer range have shown that once deer browse was removed by fencing plots or shooting deer, mountain beech seedling growth and establishment increased after only one year (Husheer and Robertson 2005; Husheer et al. 2005). Moreover, exclosure plots established during the 1980s at Kaimanawa sites with sika deer now show that mountain beech seedling and sapling abundance increased to between 2 and 25 times higher inside fenced plots compared to paired unfenced plots (Husheer 2003). In contrast, in regions with only red deer, there was little difference $(<50 \%)$ in the density of mountain beech seedlings and saplings between fenced and unfenced plots (Hurunui, Wardle et al. 2001; Murchison Mountains, Burrows et al. 1999; Rangataua, Husheer 2003).

Finally, two small-leaved shrubs ( $C$. tayloriae and $M$. divaricata), that are considered to be browse-resistant (Wardle 1984; Nugent et al. 1997; Coomes et al. 2003) were more common as seedlings in the Kaimanawa compared to other regions. This result is consistent with sika deer shifting competitive advantage away from more palatable mountain beech seedlings towards species that would be less successful in the absence of intense herbivory (Husheer et al. 2003).

Our null hypothesis that areas where sika deer had colonised most recently would show fewer signs of intense browsing by sika deer, in comparison to areas colonised first, was not supported 
by our results. There were only minor differences in abundance and basal area of overstorey species among Kaimanawa areas, and there was no significant difference in mountain beech seedling abundance. Instead, intensive browsing of mountain beech seedlings appears to occur during the early stage of sika colonisation, quickly reducing mountain beech seedling abundance, particularly at low basal area sites. These low basal area sites may be preferentially selected by deer due to higher productivity. Studies on the Isle of Rum in Scotland (Virtanen et al. 2002) and in a Swedish Boreal forest (Ball et al. 2000) have shown that productive sites are more attractive to deer. Alternatively, some studies (e.g. Moen and Oksanen 1998; Olofsson 2001) have shown that at unproductive sites, herbivores are food limited and therefore have greatest impacts (Oksanen 1990). Absolute impacts of deer may be greatest at highly productive sites, and relative impacts may be greatest at sites of lower productivity (John and Turkington 1997; Ball et al. 2000; Virtanen 2000; Takada et al. 2002). Differences in the occurrence of herbivore-resistant, small-leaved shrub species between areas with different histories of sika deer colonisation would not be detected if these plants quickly respond to competitive release. Husheer et al. (2003) showed that small-leaved species have increased in abundance as small trees within the last two decades throughout Kaimanawa Forest Park, while palatable, large-leaved species declined in abundance.

The increased occurrence of small-leaved divaricating plants under the presence of intense herbivory by sika deer has implications for recent studies concluding that divaricating plants, some of which are threatened or are in decline, are adapted to browsing by moa (Atkinson and Greenwood 1989) or to photoinhibition (Howell et al. 2002), but are poorly adapted to ungulate herbivory. Bond et al. (2004) concluded that most divaricating plants are susceptible to browsing damage from introduced ungulates but not from extant ratites. They also suggested that there is a group of small-leaved shrubs with stems $>3 \mathrm{~mm}$ diameter that are resistant to mammalian browsing. This is consistent with the results of this study and those of Wardle et al. (2002) who found that small-leaved plants, often with stems $>3 \mathrm{~mm}$ diameter, did not generally benefit from ungulate exclusion in many New Zealand regions. Most experimental studies have failed to show a benefit from the divaricating form for protection from cold, wind or low humidity (Kelly and Ogle 1990; McGlone and Clarkson 1993; Darrow et al. 2001), and so defence from herbivory may be the best explanation for this adaptation. Furthermore, climatic explanations do not show why many divaricating plant species are common across a range of habitats including the interior of forests that are sheltered from frost, wind and excessive light. We conclude that at least some divaricating plant species are resistant to intensive ungulate browsing, lowering their vulnerability to extinction.

The probable ability of sika deer to browse more intensively than red deer, and their difficulty to control due to heightened alertness and preference for dense forest habitats (Kiddie 1962), has important biological conservation implications where red and sika deer are sympatric. Sika deer have been introduced into the Czech Republic, Denmark, Germany, Great Britain, Ireland and the United States of America (Feldhamer and Marcus 1994; Goodman et al. 1996). If they are able to suppress regeneration of forests there, then sika deer may pose a serious problem for forest and conservation managers (Kelly 2002). In continental Europe, Great Britain and Ireland red deer are regarded as having the ability to adversely affect woodland regeneration (Gong et al. 1991; Scott et al. 2000). Sika deer may eliminate species that red deer are known to periodically browse such as European beech (Fagus sylvatica L.; Ammer 1996), sitka spruce (Picea sitchensis Carr.; Duncan et al. 2001), Scots pine (Pinus sylvestris L.; Scott et al. 2000) and Norway spruce (Picea abie Karst.; Gill 1992). Regeneration of these species in forests recently colonised by sika deer needs to be monitored, particularly at productive sites where the magnitude of impact may be greatest. In Scotland, sika appear to be able to competitively displace red deer, and reach higher densities (Chadwick et al. 1996) over an increasingly large area (Rose 1994). Moreover, by preferring forest or shrub habitats (Marques et al. 2001) sika may suppress forest regeneration in Europe where red deer do not (Goodman et al. 1996). If sika deer have higher levels of impacts on forest regeneration than red deer, then the 
same may be true for widespread sika-red hybrids (Abernethy 1994). This may pose additional management problems where red and sika deer are sympatric in Britain, Czech Republic, Denmark, Germany, Ireland, New Zealand and the United States of America.

\section{Acknowledgements}

We thank the hundreds of Department of Conservation and Landcare Research permanent staff, contractors and fieldworkers who collected and processed data for this study, and helped with organisation, transport, analysis and graphics. The National Vegetation Survey databank made several datasets available for this paper. Chris Frampton provided statistical advice and along with Jasper Schipperijn and Steve Deverell commented on earlier versions. The study has been funded by the New Zealand Department of Conservation (Investigation no. 2493). John Spence produced Figure 1.

\section{References}

Abernethy K (1994) The establishment of a hybrid zone between red and sika deer (genus Cervus). Molecular Ecology 3: 551-562

Allen RB (1993) A Permanent Plot Method for Monitoring Changes in Indigenous Forests. Manaaki Whenua-Landcare Research, Lincoln

Allen RB and Allan CN (1997) Mountain beech forest dynamics in the Kaweka Range and the influence of browsing animals. Science for Conservation 44: 1-23

Allen RB, Clinton PW and Davis MR (1997) Cation storage and availability along a Nothofagus forest development sequence in New Zealand. Canadian Journal of Forest Research 27: 323-330

Ammer C (1996) Impact of ungulates on structure and dynamics of natural regeneration of mixed mountain forests in the Bavarian Alps. Forest Ecology and Management 88: 43-53

Arsenault R and Owen-Smith N (2002) Facilitation versus competition in grazing herbivore assemblages. Oikos 97: 313-318

Asada M and Ochiai K (1996) Food habits of sika deer on the Boso Peninsula, central Japan. Ecological Research 11: 89-96

Asada M and Ochiai K (1999) Nitrogen content in faeces and the diet of sika deer on the Boso Peninsula, central Japan. Ecological Research 14: 249-253

Atkinson IAE and Greenwood RM (1989) Relationships between moas and plants. New Zealand Journal of Ecology 20: $67-96$
Ball JP, Danell K and Sunesson P (2000) Responses of a herbivore community to increased food quality and quantity: an experiment with nitrogen fertilizer in the boreal forest. Journal of Applied Ecology 37: 247-255

Bellingham PJ and Allan CN (2003) Forest regeneration and the influences of white-tailed deer (Odocoileus virginianus) in cool temperate New Zealand rainforests. Forest Ecology and Management 175: 71-86

Bond WJ, Lee WG and Craine JM (2004) Plant structural defences against bird browsers: a legacy of New Zealand's extinct moas. Oikos 104: 500-508

Burrows LE, Coomes DA, Newell C and Allan CN (1999) Forest vegetation changes in the Murchison Mountains, Fiordland National Park, with special emphasis on takahe management. Unpublished Landcare Research Report, New Zealand

Canham CD (1988) Growth and canopy architecture of shadetolerant trees: responses to canopy gaps. Ecology 69: 786-795

Castleberry SB, Ford WM, Miller KV and Smith WP (2000) Influences of herbivory and canopy opening size on forest regeneration in a southern bottomland hardwood forest. Forest Ecology and Management 131: 57-64

Chadwick AH, Ratcliffe PR and Abernethy K (1996) Sika deer in Scotland: density, population size, habitat use and fertility - some comparisons with red deer. Scottish Forestry 50: 8-16

Challies CN (1985) Establishment, control and commercial exploitation of wild deer in New Zealand. In: Fenessey PF and Drew KW (eds) Biology of Deer Production, pp 23-26. The Royal Society of New Zealand, Wellington

Clinton PW, Allen RB and Davis MR (2002) Nitrogen storage and availability during stand development in a New Zealand Nothofagus forest. Canadian Journal of Forest Research 32: 344-352

Conway MG (1949) The silviculture of red beech in Nelson and Westland. New Zealand Journal of Forestry 6: 291-308

Coomes DA, Allen RB, Forsyth DM and Lee WG (2003) Factors preventing the recovery of New Zealand forests following the control of invasive deer. Conservation Biology 17: 450-459

Cornett MW, Frelich LE, Puettmann KJ and Reich PB (2000) Conservation implications of browsing by Odocoileus virginianus in remnant upland Thuja occidentalis forests. Biological Conservation 93: 359-369

Darrow HE, Bannister P, Burritt DJ and Jameson PE (2001) The frost resistance of juvenile and adult forms of some heteroblastic New Zealand plants. New Zealand Journal of Botany 39: 355-363

Davidson MM (1973) Characteristics, liberation and dispersal of sika deer (Cervus nippon) in New Zealand. New Zealand Journal of Forestry Science 3: 153-180

Davidson MM (1979) Movement of marked sika (Cervus nippon) and red deer (Cervus elaphus) in the central North Island, New Zealand. New Zealand Journal of Forestry Science 9: 77-88

Davidson MM and Fraser KW (1991) Official hunting patterns, and trends in the proportions of sika (Cervus nippon) and red deer ( $C$. elaphus scoticus) in the Kaweka Range, New Zealand, 1958-1988. New Zealand Journal of Ecology 15: $31-40$ 
Davis MR, Allen RB and Clinton PW (2003) Carbon storage along a stand development sequence in a New Zealand Nothofagus forest. Forest Ecology and Management 177: 313-321

Denslow JS, Ellison AM and Sanford RE (1998) Treefall gap size effects on above- and below-ground processes in a tropical wet forest. Journal of Ecology 86: 597-609

Diamond JM (1990) Biological effects of ghosts. Nature 345: 769-770

Duncan AJ, Hartley SE and Iason GR (1994) The effect of monoterpene concentrations in sitka spruce Picea sitchensis on the browsing behaviour of red deer Cervus elaphus. Canadian Journal of Zoology 72: 1715-1720

Duncan AJ, Hartley SE, Thurlow M, Young S and Staines BW (2001) Clonal variation in monoterpene concentrations in sitka spruce (Picea sitcnesis) saplings and its effect on their susceptibility to browsing damage by red deer (Cervus elaphus). Forest Ecology and Management 148: 259-269

Elder NL (1956) North Island protection forests. New Zealand Journal of Forestry 7: 96-103

Elder NL (1962) Vegetation of the Kaimanawa ranges. Transactions of the Royal Society of New Zealand (Botany) 2: $1-37$

Endo A and Doi T (1996) Home range of female sika deer (Cervus nippon) on Nozaki Island, Goto Archipelago, Japan. Mammal Study 21: 27-35

Feldhamer GA and Marcus MA (1994) Reproductive performance of female sika deer in Maryland. Journal of Wildlife Management 58: 670-673

Fraser KW (1996) Comparative rumen morphology of sympatric sika deer (Cervus nippon) and red deer (C. elaphus scoticus) in the Ahimanawa and Kaweka Ranges, central North Island, New Zealand. Oecologia 105: 106-166

Gill RMA (1992) A review of damage by mammals in north temperate forests. 3. Impact on trees and forests. Forestry 65: 363-388

Gong YL, Swaine MD and Miller HG (1991) Effects of fencing and ground preparation of native pinewood over 12 years in Glen Tanar, Aberdeenshire. Forestry 64: 157-168

Goodman SJ, Swanson G, Vickery J and Pemberton JM (1996) The introgression of introduced Asiatic sika deer into Scottish red deer - does hybridisation matter. Deer 10: 86-90

Hanley TA (1997) The nutritional view of understanding and complexity in the problem of diet selection by deer (Cervidae). Oikos 79: 209-218

Holdaway RN and Jacomb C (2000) Rapid extinction of the moas (Aves: Dinornithiformes): model, test, and implications. Science 287: 2250-2254

Horsley SB, Stout SL and DeCalesta DS (2003) White-tailed deer impacts on vegetation dynamics of a northern hardwood forest. Ecological Applications 13: 98-118

Howell CJ, Kelly D and Turnbull MH (2002) Moa ghosts exorcised? New Zealand's divaricate shrubs avoid photoinhibition. Functional Ecology 16: 232-240

Husheer SW (2003) Impacts of deer on Kaimanawa beech forests. PhD thesis. Ecology Department, Institute of Natural Resources, Massey University, New Zealand, $183 \mathrm{pp}$

Husheer SW, Coomes DA and Robertson AW (2003) Longterm influences of introduced deer on the composition and structure of New Zealand Nothofagus forests. Forest Ecology and Management 181: 99-117

Husheer SW, Coomes DA, Robertson AW and Frampton CM (2005) Herbivory and plant competition reduce mountain beech seedling growth and establishment in New Zealand. Plant Ecology

Husheer SW and Frampton CM (2005) Wakatipu beech forest and fallow deer. New Zealand Journal of Ecology 29: $83-94$

Husheer SW and Robertson AW (2005) High-intensity deer culling increases mountain beech seedling growth in New Zealand. Wildlife Research 32: 273-280

James IL and Wallis FP (1969) A comparative study of the effects of introduced mammals on the Nothofagus forest at Lake Waikareiti. Proceedings of the New Zealand Ecological Society 16: 1-6

Jane GT (1986) Wind damage as an ecological process in mountain beech forests of Canterbury, New Zealand. New Zealand Journal of Ecology 9: 25-39

Jane GT and Pracy LT (1974) Observations on two animal exclosures in Haurangi Forest over a period of 20 years. New Zealand Journal of Forestry Science 1: 103-113

Jane GT (2005) An examination of Coprosma ciliata and C. parviflora complex. New Zealand Journal of Botany 43: 735-752

Jayasekara P and Takatsuki S (2000) Seasonal food habits of a sika deer population in the warm temperate forest of the westernmost part of Honshu, Japan. Ecological Research 15: 153-157

John E and Turkington R (1997) A 5-year study of the effects of nutrient availability and herbivory on two boreal forest herbs. Journal of Ecology 85: 419-430

Kelly D and Ogle CR (1990) A test of the climate hypothesis for divaricate plants. New Zealand Journal of Ecology 13: 51-61

Kelly DL (2002) The regeneration of Quercus petraea (sessile oak) in southwest Ireland: a 25 -year experimental study. Forest Ecology and Management 166: 207-226

Kiddie DG (1962) The sika deer (Cervus nippon) in New Zealand. New Zealand Forest Service Information Series. New Zealand Forest Service, Wellington

Marques FFC, Buckland ST, Goffin D, Dixon CE, Borchers DL, Mayle BA and Peace AJ (2001) Estimating deer abundance from line transect surveys of dung: sika deer in southern Scotland. Journal of Applied Ecology 38: 349-363

McGlone MS and Clarkson BD (1993) Ghost stories: moa, plant defences and evolution in New Zealand. Tuatara 32: $1-21$

Murray MG and Illius AW (2000) Vegetation modification and resource competition in grazing ungulates. Oikos 89: 501-508

Moen J and Oksanen L (1998) Long-term exclusion of foliovorous mammals in two artic-alpine plant communities: a test of the hypothesis of exploitation ecosystem. Oikos 82: 333-346

Nugent G (1988) Forage availability and the diet of fallow deer (Dama dama) in the Blue Mountains, Otago. New Zealand Journal of Ecology 13: 61-71

Nugent G and Fraser KW (1993) Pests or valued resources? Conflicts in the management of deer. New Zealand Journal of Zoology 20: 361-366 
Nugent G, Fraser KW and Sweetapple PJ (1997) Comparison of red deer and possum diets and impacts in podocarphardwood forest, Waihaha catchment, Pureora Conservation Park. Science for Conservation 50: 1-61

Nugent G, Fraser KW, Asher GW and Tustin KG (2000) Advances in New Zealand mammalogy 1990-2000. Deer. Journal of the Royal Society of New Zealand 31: 263-298

Ogden J, Stewart GH and Allen RB (1996) Ecology of New Zealand Nothofagus Forests. In: Veblen TT, Hill RS and Read $\mathbf{J}$ (eds) The Ecology and Biogeography of Nothofagus Forests, pp 25-82. Yale University Press, London

Oksanen L (1990) Predation, herbivory and plant strategies along gradients of primary productivity. In: Grace $\mathbf{J}$ and Tilman D (eds) Perspectives on Plant Competition, pp 445474. Academic Press, New York

Oksanen L (2001) Logic of experiments in ecology: is pseudoreplication a pseudoissue. Oikos 94: 27-38

Olofsson J (2001) Influence of herbivory and abiotic factors on the distribution of tall forbs along a productivity gradient: a transplantation experiment. Oikos 94: 351-357

Parkes JP, Tustin KG and Stanley L (1978) The history and control of red deer in the takahe area, Murchison Mountains, Fiordland National Park. New Zealand Journal of Ecology 1: 145-152

Parsons MJ, Douglass P and Macmillan BH (1995) Current Names List for Wild Gymnosperms, Dicotyledons and Monocotyledons (except Grasses) in New Zealand. Manaaki Whenua Press, Lincoln, New Zealand

Peterson CJ, Carson WP, McCarthy BC and Pickett STA (1990) Microsite variation and soil dynamics within newly created treefall pits and mounds. Oikos 58: 39-46

Peterson CJ and Pickett STA (2000) Patch type influences on regeneration in a western Pennsylvania, USA, catastrophic windthrow. Oikos 90: 489-500

Pickett STA and White P (1989) The Ecology of Natural Disturbance and Patch Dynamics. Academic Press, New York

Poole AL and Adams NM (1994) Trees and Shrubs of New Zealand. Manaaki Whenua Press, Lincoln

Riney T (1957) The use of faeces counts in studies of several free-ranging mammals in New Zealand. New Zealand Journal of Science and Technology 38: 507-532

Rose H (1994) Scottish deer distribution survey 1993. Deer 9: 153-155

Russel FL, Zippin DB and Fowler NL (2001) Effects of whitetailed deer (Odocoileus virginianus) on plants, plant populations and communities: a review. American Midland Naturalist 146: 1-26

Scott D, Welch D, Thurlow M and Elston DA (2000) Regeneration of Pinus sylvestris in a natural pinewood in NE Scotland following reduction in grazing by Cervus elaphus. Forest Ecology and Management 130: 199-211

Sokal RR and Rohlf FJ (1995) Biometry. W.H. Freeman, New York

SPSS (2000) SYSTAT 10.0. SPSS Inc, Chicago, USA
Stewart GH and Harrison JBJ (1987) Physical influences on forest types and deer habitat northern Fiordland, New Zealand. New Zealand Journal of Ecology 10: 1-10

Stewart GH, Wardle JA and Burrows LE (1987) Forest understorey changes after reduction in deer numbers, Northern Fiordland, New Zealand. New Zealand Journal of Ecology 10: 35-42

Takada M, Asada M and Miyashita T (2002) Cross-habitat foraging by sika deer influences plant community structure in a forest-grassland landscape. Oecologia 133: 389-394

Takatsuki S and Gorai T (1994) Effects of sika deer on the regeneration of a Fagus crenata forest on Kinkazan Island, northern Japan. Ecological Research 9: 115-120

Takatsuki S and Ikeda S (1993) Botanical and chemical composition of rumen contents of sika deer on Mt Goyo, northern Japan. Ecological Research 8: 57-64

Takahashi H and Kaji K (2001) Fallen leaves and unpalatable plants as alternative foods for sika deer under food limitation. Ecological Research 16: 257-262

Ter Braak CJE and Smilauer P (1998) CANOCO 4.0. Centre of Biometry, Wageningen, The Netherlands

Tsujino R and Yumoto T (2004) Effects of sika deer on tree seedlings in a warm temperate forest on Yakushima Island, Japan. Ecological Research 19: 291-300

Virtanen R (2000) Effects of grazing on above-ground biomass on a mountain snowbed, NW Finland. Oikos 90: 295-300

Virtanen R, Edwards GR and Crawley MJ (2002) Red deer management and vegetation on the Isle of Rum. Journal of Applied Ecology 39: 572-583

Wardle DA, Barker MB, Yeates GW, Bonner KI and Ghani A (2001) Introduced browsing mammals in New Zealand natural forests: aboveground and belowground consequences. Ecological Monographs 71: 587-614

Wardle DA, Bonner KI and Barker GM (2002) Linkages between plant litter decomposition, litter quality, and vegetation responses to herbivores. Functional Ecology 16: 585-595

Wardle JA (1970) The ecology of Nothofagus solandri. 3. Regeneration. New Zealand Journal of Botany 8: 571-608

Wardle JA (1984) The New Zealand Beeches. New Zealand Forest Service, Wellington

Wardle JA and Guest R (1977) Forests of the Waitaki and Lake Hawea catchment. New Zealand Journal of Forestry Science 7: 44-67

Wardle P (1962) Subalpine forest and scrub in the Tararua Range. Transactions of the Royal Society of New Zealand (Botany) 25: 435-439

Wilson CJN (1993) Stratigraphy, chronology, styles and dynamics of late quaternary eruptions from Taupo volcanoes, New Zealand. Philosophical Transactions of the Royal Society, London, Series A 343: 205-306

Wilson HD and Galloway T (1993) Small-leaved Shrubs of New Zealand. Manuka Press, Christchurch

Wiser SK, Bellingham PJ and Burrows LE (2001) Managing biodiversity information: development of New Zealand's National Vegetation Surveys databank. New Zealand Journal of Ecology 25: 1-18 